Mehmet SEVGIN

DOI : $10.14746 /$ pp.2021.26.4.9

University of Wroclaw

ORCID ID: 0000-0003-2167-6838

\title{
The impacts of cognitive biases and heuristics on Covid-19 preventive behaviors
}

\begin{abstract}
The covid-19 pandemic disease became part of the study of many scientific disciplines recently since its impact area is large and it threatened millions of lives. One of the important disciplines is public policy since the characteristics may easily influence the spread of covid-19. It is assumed that an individual's irrational tendencies can increase this spread since they are highly correlated with the most important actions of prevention of the spread such as isolation, wearing a mask, and washing hands. Moreover, public policies can be effective in such a pandemic period if they take into consideration of individual's irrational tendencies. Hence, in this study the psychological background of why individuals do not follow the regulations that can decrease the spread of covid-19 will be presented: cognitive biases and heuristics.
\end{abstract}

Key words: bounded rationality, cognitive biases and heuristics, covid-19, preventive behaviors

\section{Introduction}

A s a well-known fact, the covid-19 pandemic disease spread worldwide and caused millions of death. Although the vaccinations were applied successfully to many people, the spread did not stop due to the new variants of the virus and the low speed of vaccinations. Hence, covid-19 is still a danger for society and the precautions should be maintained. More specifically, encouraging people to preventive attitudes must be the main focus of the public policies to decrease the spread of covid-19 (Soofi, Najafi, Karami-Matin, 2020).

It is assumed that the precautions can be the study of behavioral economics and insights from it may help to stop the spread of covid-19. Because, although the danger is obvious, the estimation of the exact damage of the virus may not be accurate due to humans' low capacity of cognitive abilities. Moreover, doing the precautions may require strong motivation. For instance, many people would like to go to the gym, smoke less, eat more healthily, save more money. However, not all people who are willing to do such healthy behaviors are doing them in real life and that is because of the nature of humans: avoiding small, short term pain and welcoming a bigger, long term pain which may even cause death. Individuals may care about the short-term gains and losses more than the long-term gains and losses.

In the first section of this study, some cognitive biases and heuristics that may influence an individual's preventive behaviors during pandemic periods will be discussed from the perspective of behavioral economics and bounded rationality. Although there are more than 100 cognitive biases and heuristics, only the ones that are related to pan- 
demic period behaviors will be the subject of this study. In the next section of this study, rationality term in economics will be discussed.

\section{Rationality Term in Economics}

The assumptions of standard economics describe humans as selfish, rational, and insensitive species. According to this view, since humans are extremely rational about their choices, they do not mix their feelings with their choices. However, rationality should be questioned due to the violation examples of rationality term through real-world observations and controlled experiments, individuals no longer can be considered as fully rational. Behavioral economics is a branch of economics that benefits from psychological methods to support economics. According to Camerer (1999, 10575); "Behavioral economics improves the realism of the psychological assumptions underlying economic theory, promising to reunify psychology and economics in the process. Reunification should lead to better predictions about economic behavior and better policy prescriptions."

The main criticism of behavioral economics to standard (main-stream, neoclassical) economic assumptions is based on the rationality principle in economics as mentioned above. According to behavioral economics, individuals have "bounded" rationality rather than perfect rationality. Before discussing bounded rationality, we must know what standard economic assumptions refer to rationality in economics.

Rabin (2002, p. 4) postulates that the term "homoeconomicus" or "economic man" is used by standard economic models that describe humans as self-interested, rational, and capable to do rational choices even in complex situations. Moreover, they ignore moral and ethical values when they make rational choices. It is also assumed that this man has an efficient and solid system of preferences. What is more, he is also marked by an ability to calculate due to which he can make an alternative computation that is accessible in his case. All of the things mentioned above are crucial as they allow him to get to the highest available point of his scale of preferences (Simon, 1955, p. 99).

However, Simon also posits the view that this level of rationality is not valid in real-life examples. Experimental findings of an individual's behaviors systematically violate the principles of rationality. Therefore, bounded rationality is a better word to describe the economic behavior of individuals. Bounded rationality is a term which claims that the rationality of individuals is limited because of several factors such as environmental limitations, time constraints, and cognitive limitations of the human brain. This term is first discussed by Herbert Simon in 1955 in his study "Theories of Bounded Rationality" (Simon, 1972, pp. 161-176).

According to Simon (1972, pp. 163-164), three factors bound the rationality of individuals. The first one states that individuals do not have perfect knowledge of demand and cost functions, they are rather informed about their distributions. This change in the assumption might lead individuals to face several difficulties to find the optimum choice. In the case of uncertainty and risk, it becomes even more difficult to reach the optimum value compared to certain situations. The second factor which bounds rationality is that the individuals have incomplete information about alternatives. Therefore, the question of finding the best alternative switches to the question of how much the individuals' resources should be used 
to search for action. The last factor which the author claim that bound the rationality is related to the complexity of the cost function and environmental constraints. The existence of these notions prevents individuals to calculate the best option among alternatives. In the next section of this study, some cognitive biases and heuristics that we believe that are related with covid-19 preventive behaviors will be presented.

\section{Cognitive Biases and Heuristics During Covid-19 Pandemic Period}

Cognitive biases and heuristics, as a term, were first introduced by Kahneman and Tversky at the beginning of the 1970s. Their researches about cognitive biases and heuristics were addressed to the individual's decision-making process under limited sources. These researches were inspired by Simon's bounded rationality concept (Wilke, Mata, 2012, p. 531). For instance, Furnham and Boo (2011, p. 25) assume that this bounded rationality model can be considered as a "model of heuristic cognition" too.

Although the terms "bias" and "heuristic" are very similar, they represent different things. To avoid this confusion, we would like to explain their meanings. The heuristic can be defined as mental shortcuts that simplify the decision-making process by helping individuals to make quick and efficient decisions. Bias is the result of the application of one or more heuristics. "Cognitive bias is a systematic deviation from rationality in judgment and decision-making common to all human beings which can be due to cognitive limitations, motivational factors, and/or adaptations to natural environments." (Wilke, Mata, 2012, p. 531).

Cognitive biases might occur as a result of short-cuts and fast thinking processes. They mostly work as automatic and it might be difficult to avoid them. Although in some cases they might be useful, they may lead individuals to make biased decisions too. There are more than 100 cognitive biases and heuristics (Ehrlinger, Readinger, Kim, 2016, p. 3).

However, in this study, we decided to focus on the ones which may prevent people to follow the pandemic period regulations that decrease the spread of diseases. Hence, the cognitive biases and heuristics we would like to analyze in this study are:

- Present Bias,

- Bandwagon Effect,

- Optimism Bias,

- Status Quo Bias,

- Framing Effect,

- Self-Control Problem,

- Irrational Beliefs.

\section{Present Bias}

Adam Smith in his famous book "The Theory of Moral Sentiments" states that: "The pleasure that we are to enjoy ten years hence, interests us so little in comparison with that which we may enjoy today" although present bias was discovered by behavioral 
economists (Smith, 2010, p. 102). Hence, due to the existence of present bias, individuals may choose today's losses and gains over tomorrow's. For instance, Thaler and Benartzi (2004) demonstrate that one of the main reasons why people do not save enough is because of people's choice today over tomorrow. Hence, they spend today instead of saving for their retirement.

When it comes to the covid-19, individuals tend to be fond of today's pleasure by going to pubs, shopping centers, restaurants, weddings, funerals, and spending unnecessary time outside over tomorrow's pain. However, as it is a well-known fact, the more people are outside, the higher the risk of getting caught of covid-19 and the longer the pandemic period may last. Thus, present bias may prevent individuals to follow the regulations for covid-19.

\section{Bandwagon Effect}

The bandwagon effect is the tendency of following other people's preferences and lifestyles rather than following self-preference. Doing something just because others are doing it like that (Lechanoine, Gangi, 2020, p. 1). When people go outside and see others who do not follow the regulations, they may tend to follow what they do and vice versa. Moreover, if those people who do not follow the regulations do not catch the virus, this may encourage people not to follow the regulations as well.

\section{Optimism Bias}

People may underestimate dangerous situations and lower the probability of crossing such bad events in their lives. This is called optimism bias. The longer people do not catch the virus, the less they may believe in its existence. Moreover, people may overestimate their immune systems as well. According to the Dunning-Kruger effect, people may overestimate their knowledge, ability, and capacity in a certain issue or subject. They may consider the disease as regular flu or cold too. Hence, this will decrease the danger level of the disease in their eyes and they will not follow the regulations. Perception bias is another reason that people may consider covid-19 as regular flu or cold (Mohamed et al., 2021, p. 2). It refers to the tendency of perceiving the situation from a stereotypical perspective and it prevents looking at it with objective eyes. For instance, some symptoms of flu and cold are very much similar to the covid-19 disease Therefore, people may easily consider them as flu or cold and convince themselves that such things do not exist and no need to follow the regulations.

\section{Status Quo Bias}

Status quo bias refers to the tendency of not changing the current situation or doing nothing when there is a new situation even (Samuelson, Zeckhauser, 1988, p. 8). Individuals may be stick to the status quo even if changing might bring better outcomes 
than the current situation. It is possible to see some status quo biases in our daily lives. For instance, Coca Cola that is considered as one of the most consumed drink all over the world has an interesting story that we can relate to status quo bias. In 1985, when Coca Cola company launched a new version of Coca-Cola, the producers put it to the blind test. The results demonstrated that most of the people chose New Coke over the Coke Classic. However, when they started to sell both versions of cokes in the market, consumers continued drinking the classic one. This inconsistency of behaviors occurs because of the existence of status quo bias (Samuelson, Zeckhauser, 1988, p. 11). However, such behaviors can not be considered rational since changing the current position or status quo may open better doors.

During the covid-19 pandemic period, many people objected to the regulations since they claim that this is an imposition and the governments restrict their freedoms. Although it is very obvious that covid-19 cost a lot to the whole world, some people preferred to protect their status quo and forget about the danger of the disease. This can be explained by the existence of status quo bias strongly. Hence, this is another reason why people may not follow the regulations of the covid-19 (Haddad, 2021).

\section{Framing Effect}

The framing effect assumes that decision-makers make their choices depend on how a set of identical choices is presented (Gonzalez et al., 2005, p. 2). Individuals might act differently to the same things, events, or situations when they are presented differently. Framing a glass as "half full" or "half empty" has different meanings and it might evoke different feelings. Individuals may be influenced by different frames of an equal outcome, partly due to the formulation of the problem and partly due to the habits and personalities of decision-makers (Tversky, Kahneman, 1981, p. 453). For instance, 400 people among 600 people will be saved with treatment is not the same as 200 people among 600 people will be lost due to that treatment are not the same although they look the same mathematically. According to the results in a study, participants presented different answers to those options we mentioned above (Kahneman, Tversky, 1984, p. 346).

All governments all around the world started to inform the public regarding the statistical data of coronavirus pandemic disease. The way of presenting the daily case numbers and death rates may influence the way people are treated to the covid-19 disease. For instance, when people see the death rate among all the cases, they may perceive it as regular flu, and the probability of dying is not very high. Especially young people may trust their immune system and do not follow the regulations. However, death rates and case numbers may be shown in different ways that people may perceive it more dangerous and care about the preventive behaviors more.

Yet, visual frames about how covid-19 patients suffer even if they do not die may lead people to follow the regulations. Moreover, the death rate and contagious level of flu or regular cold may present as well to make people understand that covid-19 is more dangerous. Furthermore, the reduction in the case numbers and death rates may be easily perceived as "the pandemic is over" by people (Narinder, 2020). 


\section{Self Control Problem}

Lack of self controls another important reason why individuals do not obey the rules during a pandemic period. In general, everyone can plan something on their minds and force them to do healthy behaviors. However, when it comes to applying such plans, in reality, it may be challenging. People might want to save more, eat healthier, go to the gym more, smoke less, consume less energy. However, they may not be successful due to their lack of cognitive ability and willpower or the complexity of the duty (Sevgin, 2020, p. 872 as cited in Madrian, 2014, p. 11). In the pandemic period, not socializing and maintaining a "normal" daily life is a challenging issue for humans as they are sociable species. As food, water, air are physical requirements to live for humans, socializing is a psychological human need. Moreover, changing their life-long behaviors suddenly is another challenge as we discussed under the tile of status quo bias. Therefore, limiting this requires strong self-control.

\section{Irrational Beliefs}

People may have irrational beliefs especially in such chaotic environments like pandemic periods that do not occur often. There may be a lot of myths, information pollution as well. Moreover, some people may easily pass the regulations since they may believe that everyone will catch it, in the end, there is no need to follow the regulations and escape from it. It is easy to convince people to have wrong beliefs in such an environment when there is not enough scientific research.

\section{Conclusion}

The covid-19 pandemic disease maintaining damaging humans' lives despite the high speed of vaccination all around the world. Thus, the spread of the virus is still threatening the world. In this study, we discussed several cognitive biases and heuristics that we believe may help to decrease the spread of the virus. It is assumed that such research about cognitive biases and heuristics is very important to understand the problem of why humans do not obey the regulations. According to our findings, present bias, bandwagon effect, optimism bias, status quo bias, framing effect, self-control problem, and irrational beliefs are the cognitive biases and heuristics that are sort of a set in front of preventive behaviors. Hence, we believe that understanding the nature of irrational tendencies of humans, more specifically the nature of the cognitive biases and heuristics may be useful for preparing effective public policy designs during a pandemic period.

\section{Bibliography}

Camerer C. F. (1999), Behavioral Economics: Reunifying Psychology and Economics, "Proceedings of the National Academy of Sciences", vol. 96 (19)

Ehrlinger J., Readinger W. O., Kim B. (2015), Decision-Making and Cognitive Biases, in: Encyclopedia of Mental Health, vol. 2. 
Furnham A., Hua Chu Boo (2011), A Literature Review of the Anchoring Effect, "The Journal of Socio-Economics", vol. 40(1).

Gonzalez C., Dana J., Koshino H., Just M. (2005), The Framing Effect and Risky Decisions: Examining Cognitive Functions With fMRI, "Journal of Economic Psychology", vol. 26(1).

Haddad M. (2021), https://www.aljazeera.com/news/2021/2/2/mapping-coronavirus-anti-lockdown-protests-around-the-world, 15.07.2021.

Kahneman D., Tversky A. (1984), Choices, Values, and Frames, “American Psychologist”, vol. 39(4).

Lechanoine F., Gangi K. (2020), COVID-19: Pandemic of Cognitive Biases Impacting Human Behaviors and Decision-Making of Public Health Policies, "Frontiers in Public Health", vol. 8.

Mohamed K., Yazdanpanah N., Saghazadeh A., Rezaei N. (2021), Cognitive Biases Affecting the Maintenance of COVID-19 Pandemic, "Acta Bio Medica: Atenei Parmensis", 92(2).

Narinder K. (2020), Covid-19 cognitive bias, https://blogs.bmj.com/bmj/2020/06/09/covid-19-andcognitive-bias/, 11.07.2021.

Rabin M. (2002), A perspective on psychology and economics, "European economic review", 46(4-5).

Samuelson W., Zeckhauser R. (1988), Status Quo Bias in Decision Making, "Journal of Risk and Uncertainty", vol. 1(1).

Sevgin M. (2020), Public Policy Implications of Cognitive Biases and Heuristics, "The Journal of International Social Research", 13(72) (as cited in Madrian B. C. (2014). Applying Insights From Behavioral Economics to Policy Design, “Annu. Rev. Econ.”, vol. 6 (1)).

Simon H. A. (1955), A Behavioral Model of Rational Choice, "The Quarterly Journal of Economics", vol. $69(1)$.

Simon H. A. (1972), Theories of Bounded Rationality, "Decision and Organization", vol. 1(1).

Smith A. (2010), The theory of moral sentiments, "Penguin".

Soofi M., Najafi F., Karami-Matin B. (2020), Using insights from behavioral economics to mitigate the spread of COVID-19, "Applied health economics and health policy", vol. 18(3).

Thaler R. H., Benartzi S. (2004), Save More Tomorrow "M. Using Behavioral Economics to Increase Employee Saving, "Journal of Political Economy", vol. 112(1).

Tversky A., Kahneman D. (1981), The framing of decisions and the psychology of choice, "Science", vol. 211(4481).

Wilke A., Mata R. (2012), Cognitive Bias, “The Encyclopedia of Human Behavior”, vol. 1.

\section{Wpływ uprzedzeń poznawczych i heurystyk na zachowania profilaktyczne Covid-19}

\section{Streszczenie}

Choroba pandemiczna Covid-19 stała się ostatnio przedmiotem badań wielu dyscyplin naukowych, ponieważ obszar jej oddziaływania jest duży i zagraża milionom istnień ludzkich. Jedną z ważnych dyscyplin jest polityka publiczna, ponieważ jej charakter może łatwo wpływać na rozprzestrzenianie się wirusa Covid-19. Zakłada się, że irracjonalne skłonności jednostki mogą zwiększyć rozprzestrzenianie się choroby, ponieważ są one silnie skorelowane z najważniejszymi działaniami zapobiegającymi rozprzestrzenianiu się choroby, takimi jak izolacja, noszenie maski i mycie rąk. Co więcej, polityka publiczna może być skuteczna w okresie pandemii, jeśli uwzględnia irracjonalne skłonności jednostki. Dlatego też w niniejszym opracowaniu przedstawione zostanie psychologiczne podłoże tego, dlaczego jednostki nie przestrzegają przepisów, które mogą zmniejszyć rozprzestrzenianie się wirusa Covid-19: uprzedzenia poznawcze i heurystyki.

Słowa kluczowe: ograniczona racjonalność, uprzedzenia poznawcze i heurystyki, Covid-19, zachowania prewencyjne

Article submitted: 19.10.2021; article accepted: 15.11.2021. 
